\title{
EMPLOYEES' CAREER TRANSITION AND GROWTH: A STUDY OF WOMEN-OWNED MICRO BUSINESSES IN BALOGUN MARKET, LAGOS, NIGERIA
}

\author{
Chinazor, Lady-Franca OBUNIKE \\ AE-FUNAI, Ebonyi State, Nigeria \\ Corresponding author's e-mail: ladyfranca8@gamil.com
}

\begin{abstract}
The study aims at investigating the effect of voluntary career transition on women-owned micro business growth. The independent variable 'voluntary career transition' is used as a single construct while the dependent variable 'business growth' is decomposed as a multi-construct of sales, employees and assets growth. The population of the study comprises 384 persons, while the sample size used is 250 micro businesses owned by women, who are formal employees of organisations. Average distribution is used to select the number of questionnaires that were distributed by the ten lines of business selected for the study. The study employs self-constructed questionnaire items to measure the independent, while an adopted questionnaire is used for firm growth. Frequencies and descriptive statistics are used to analyse the data collected from 104 questionnaire respondents, while the regression analysis is used to test the hypotheses. The findings indicate that voluntary career transition has a very high positive effect on the employment creation, a high positive effect on the sales growth and a very low positive effect on the asset growth of the business under study. The study, therefore, concludes that although carrier transition from paid employment to micro-businesses might be a difficult carrier choice and unattractive decision, for most women, it has been proven to be a contributing factor that affects the growth of women micro business. The study, therefore, suggests that organisational management and policymakers should encourage intrapreneurs and micro businesses.
\end{abstract}

Keywords: Business Growth, Career Transition, Employees' Resignation, Employees' Retirement, Involuntary Transition, Voluntary Transition.

JEL Classification: M13, M51

\section{INTRODUCTION}

The issue of growth of micro, small and medium enterprises (MSMEs) remains a great concern to every nation like Nigeria that is willing to promote its economic growth. In Nigeria, different agencies such as Small and Medium Enterprises Development Agency of Nigeria (SMEDAN), National Economic Empowerment and Development Strategy (NEEDS), Family Economic Advancement Programme (FEAP) and others have been established to administer loans, provide facilities, grants and ensure the growth of these enterprises among others. MSMEs, especially women-owned micro businesses, play an important role in reducing poverty through wealth and job creation, facilitating national economic development and 
growth. Studies calculate an increase in GDP using the number of new women participating in business. According to the studies of SMEDAN and the National Bureau of Statistic (NBS) Collaborative Survey, Selected Findings (2013), MSMEs constitute $97 \%$ of all businesses in Nigeria and generate about $50 \%$ of the employment. The survey study of SMEDAN and NBS (2013) also finds that there are over 36, 9994,578 micro businesses in Nigeria with 3,224,324 micro businesses in Lagos State, which employs over 59,741,211 representing $84 \%$ of the total labour force in Lagos State. Nzewi, Onwuka, and Onyesom (2017) are of the opinion that most of these businesses are established by women and they are mainly seen in informal sectors. Sarwoko, Surachman, and Hadiwidjojo (2013) group the factors that affect women business performance and growth into personal and organisational factors. The personal factors among others include demography, competence, character features and the intention of the business owner, while the organisational factors include company competence, organisational culture and structure.

Most career women who do not like to be saddled with office engagements alone and also most retirees who are comfortable staying at home with their unemployed children have devised a strategy to grow their income. Many of these career women instead of retaining their employment at a particular organisation either voluntarily resign or apply for retirement to be fully engaged in their already established micro businesses. This shows that such voluntary career retirees are still energetic enough to embark on a new line of business actively. This helps alleviate the stress and anxiety associated with this major life change. Many of them use the services of paid employees to actively operate their businesses. Nonetheless, many women employees find it difficult to engage in any micro business due to the stress of office work cum family roles. It is therefore, observed that a decision regarding career transition tends to be complex for most women (Obunike, 2016a). It is not an easy decision for a woman to voluntarily transit from paid employment to micro business where the woman takes the risk of initiating her own business, and sees the socio-cultural barriers associated with her self-employment.

Career is a boundary-less dynamic developing concept that is described as a series of jobs, roles, positions, activities, and experiences held by an individual in the context of employment. It is viewed as the unfolding sequence of a person's work experience over time (Chen \& Thompson, 2016). A transition is as an event or non-event that results in a change in the expectations of an individual and the environment and thus requires a corresponding change in one's behaviour and relationships. Hall and Suddharth (2015) define career transition as involving different relationships and roles and change in assumptions and routines. Career transition, therefore, is defined as a subset of work role changeovers that include a change of employers along with some degree of change in the actual job or work role as well as the subjective perception of such changes. It requires adjustment and changes in self-concept, cognition, motivation and attitudes. Career transition as used in this context refers to change of jobs, profession or one's orientation to work. It is a period in which someone undergoes changes in occupation and passes from one occupation to another. Most women entrepreneurs are corporate intrapreneurs; they approach their work in an entrepreneurial way at formal organisations. They 
are highly creative and innovative at their formal organisations. Career may be outwardly manifested by a rise in rank and promotion through a series of positions in a hierarchy of prestige, benefits and salary and inwardly reflected in the individual's personal perspective of her roles and of the significance of events surrounding her. In the present study, the career transition is used to mean a change from an employee to an employer. It is considered to be voluntarily transition from paid employment to self-employment. The women career development is nonlinear, complemented and highly frustrated by multiple-role engagement and is also shaped by the structure of opportunity in a larger social context.

In Lagos state, most employed women gradually acquire shops at Balogun market; they visit their shops at the closure of work each day and fully on weekends and public holidays. Some of them are seen hawking wares and other tangible things even in their offices using their cars as shops. Others acquire shops at their residence, too. An interactive visit to some women micro business owners at Balogun market revealed that most of them were either pushed into micro business because there was no other alternative after retirement, or pulled into the micro business due to business opportunities; hence, they resigned from their previous career. Self-employment becomes the option if the total derived utility expected from self-employment is greater than the total utility offered by the paid employment option (Obunike, 2016b). Therefore, the issue of career transition in and out of organisations becomes very indispensable for employees and organisations.

Growth shows the progressive report of a firm's stated objectives. It is defined as how well a firm performs relative to the goals it sets for itself. The high-potential women enterprises show that the businesses are highly innovative, market expanding and export-oriented. Scholars and international bodies, therefore, have established common challenges among these enterprises, which include among others "business growth". Although micro businesses established by women lack growth compared to that of men and hence do not survive more than five years of establishment (Ebitu, Basil \& Ufot, 2016; OECD, 2017), a woman micro business with growth objective is expected to have an increased number of employees, increased assets growth (business expansion) and increased sales growth (financial growth). Most women have no intention of growing their businesses due to domestic work and family responsibilities. Many of these businesses established by these retirees and voluntarily resigned women are successful while the majority of them are struggling for growth and survival. An interactive visit to Balogun market shows that many women who are business owners are career women or 'organisational products'. Blumberg and Pfann (2016) affirm that most new firms are formed by formal employees.

Statement of Problem. Despite the fact that women-owned businesses are growing at a faster rate, they remain underrepresented as entrepreneurs since a majority of these businesses lack growth compared to their men counterparts and they either fail in the first five years of activity or remain very small (OECD, 2017). However, a micro business that embarks on a growth objective can turn to high potential enterprises. Some women micro business owners in Balogun market are either pushed into micro business because there is no alternative employment after 
retirement or pulled into the micro business due to business opportunities; hence, they resigned or retired from their previous jobs. The knowledge gained from previous employment is essential for micro business growth; hence, organisation employment is the source of most business ideas and growth. Therefore, a potential Balogun woman business owner with previous work experience may be in a better position to grow a business than those without previous work experience. Based on this fact, the researcher deems it fit to study whether the previous organisational knowledge and experiences aid the growth of micro businesses owned by these women.

Objective of the Study. The major objective of the present study is to investigate the effect of voluntary career transition on the growth of women-owned micro businesses. Other specific objectives are as follows:

1) to examine the effect of the voluntary career transition on the number of employees of the women-owned micro businesses;

2) to determine the effect of the voluntary career transition on the sales growth of the women-owned micro businesses;

3) to determine the effect of the voluntary career transition on the asset growth of the women-owned micro businesses.

Research Questions:

1) Does voluntary career transition positively affect the number of employees employed by the women-owned micro businesses?

2) Does voluntary career transition positively affect sales growth of the women-owned micro businesses?

3) Does voluntary career transition positively affect asset growth of the women-owned micro businesses?

\section{LITERATURE REVIEW}

\subsection{Meaning and Dimensions of Career Transition}

Career transition can be intentional or unintentional. Sanzenbacher, Sass and Gillis (2017) argue that employees transit voluntarily for a better job and involuntarily after a job loss; thus, we have two types of career transition:

1) voluntary or intentional career transition and

2) involuntary or unintentional career transition.

\subsubsection{Voluntary/Intentional Career Transition}

This include those changing jobs or careers and those choosing to leave the paid employment work due to personal reason(s). Intentional transition embraces resources based theory of Penrose. This focuses on the enterprises' resources such as expansion of business, financial resources, acquired skills and competencies. The opportunity-based transition is often made with enough time, resource and competence to consider all the alternative opportunities available. It then means that opportunity-based women entrepreneurs are more likely to result in successful adjustment as they make use of both internal and external resources to implement the transition plan. Voluntary transition results in negative consequences for 
organisations as the loss of their key employees and intrapreneurs limit organisational competitive abilities due to the shortage of intangible assets of its human resources. It then means that the more resources (human capital assets) an employee possesses, the more likely the employee quits the organisation voluntarily. It also affects those employees' colleagues who do not transit, as it limits the transfer of intangible resources such as technical know-how and experts' experiences that are inherent in employees and not with the organisation. It, therefore, affects the entire organisational performance. Intentional careers are more prone to succeed in business than the unintentional career. The woman employee transiting to micro business is both physically and psychologically prepared to make use of both internal and external resources, competence acquired during being employed to implement the transition plan. Examples of intentional/voluntary transition include voluntary resignation and voluntary retirement.

Voluntarily Resignation: Women managers are more likely to voluntarily resign their position twice than their men counterparts (Murphy, 2017). A major explanation for this phenomenon is the existence of invisible artificial barriers created by attitudes and prejudices in the organisations (Obunike, 2018). Some employees can voluntarily resign from paid work to transit to micro enterprises when they discover an opportunity whose perceived cost is higher than remaining in the employment that gives the employees' human and social capital resources. However, other employees may discover entrepreneurial opportunities and wish to transmit; only a few may actually transit since Duberley, Carmichael, and Szmigin (2014) note that not all discovered opportunities are brought to realisation.

Voluntarily Retirement: Dingemans and Henkens (2014) define retirement as an abrupt and complete discontinuation of paid employment in later life. Older employees may voluntarily retire earlier than supposed using appealing retirement arrangements or keep working at a formal organisation until the official public pension age. It is also observed that most formal organisations include retirement planning programmes in their objectives; as they consider it necessary to train their employees especially those in the retirement age on how to remain actively independent. This enables the retirees to compete and grow their businesses as it remains the only source of livelihood for most of them. Retirement is more positive when it can enable employees to restructure and redefine their roles. Some employees after voluntarily retirement decide to still retain a "bridge employment", i.e., being retired from one organisation but still employed in some type of paid job. This can be done as a result of a carefully planned decision of an employee. Others may retire to be fully self-employed. Most employees look forward to their retirement from the organisation. After long years of active service, moving from one sector to another, the employee must have been loaded with experiences, skills and knowledge. Self-employment plays an important role in the retirement period because it is yet another component of a diverse pattern of labour force among today's older ones. It gives one an opportunity to still be active even after leaving the paid job and offers a balanced growth and decline at the crossroads of youth and old age (Lachman, Teshale \& Agrigoraei, 2015). Campbell (2012) argues that the consequences of voluntary retirement on life satisfaction have been found to 
positively impact retirees; some also retire due to health issues, and hence they perceive it as forced.

\subsubsection{Involuntary/Unintentional Career Transition}

Unintentional career transition is shaped by personal and environmental constraints. Employees find it very traumatic when they are forced to either resign or retire. They, therefore, suffer from a series of diverse consequences. They often have difficulty in going back to the labour market in search of employment: they earn significantly less in a new job, and are twice as likely as otherwise similar employees to retire by given age. The employees face an entirely new beginning in life unprepared that affects every other area of life. This frustration can trigger entrepreneurship as a necessity not as the opportunity based. They are not given enough time, therefore, to prepare for the transition; hence, the necessity-based entrepreneurship establishes new enterprises in the long-term unemployed with limited capital and entrepreneurial skills and competencies. They may lack the necessary skills, competencies and resources to transit to another work. Their nature of entrepreneurship being pursued, therefore, is relatively weak with respect to product and process innovation, company growth, product quality and spatial reach of markets. Some involuntary career transited employees may end up with loss of employees' job or necessitate adjusting to the same work environment but require individuals to develop new ways to approach tasks and develop new skills. This situation demands self-determination and courage. Many employees end up with it while the vast majority will not only survive it but end up in a position that is at least better than where they were before (Grigore \& Toma, 2014). Self-employment through SMEs can turn work devastating personal tragedy into a personal and professional triumph. Examples of involuntary transition include those who are laid-off, those facing forced retirements and those forced to re-enter into labour force because of policy changes such as changes in personal circumstances like divorce, widowhood, change in their work environment, for instance, merger and acquisition, relocation of the labour force, out-sourcing of work tasks to an outside firm or revamping of the work environment through technological change. Sanzenbacher, Sass and Gillis (2017) observe that unintentional career transition can impact employees' physical and mental health such as depression, frustration and substance abuse.

\subsubsection{The Dimension of Micro Business Growth}

The OECD (2017) defines micro businesses as enterprises whose paid employees are between one to nine (1-9) and with capital not more than one million five hundred thousand nairas $(\mathrm{N} 1.5 \mathrm{M})$, including working capital but excluding the cost of land and/or a labour size of not more than nine workers. A woman-owned micro business is a micro enterprise that a woman has taken initiative to launch, accept the associated risks and is effectively in charge of its day-to-day management (Obunike, 2018). It is a business a woman takes the responsibility of financing, nurturing and growing. Firm growth is an important indicator of a thriving economy. Growth assesses organisational activities for persistent progress in order 
to determine what has been achieved and what needs to be achieved. Growth is a gradual process that might not be noticed in a short period of time. Seventy percent (70\%) of women-owned enterprises start as a micro business (Srivastava, 2017). The dimension of micro business growth used in this study includes an increased number of employees, asset growth and sales growth. The number of employees reflects how the internal processes are organised and adapt to changes in activities of the organisation. It analyses the aspects of organisational activities such as labour policies, labour market evolution and job creation. Asset growth refers to acquisition of assets. It is one of the measures of firm growth. This signifies profit growth and increased performance especially with tangible assets. Tangible and intangible assets are also the source of competitive advantage for firms. Increased sales growth shows the prices and quantities sold on the market. Sales are easily available and relatively insensitive to capital intensity.

\subsection{Empirical Review}

Serazul's (2012) study on pull and push factors towards women small entrepreneurship development in Bangladesh had the objective to study and identify the reasons why the entrepreneurs became motivated and were compelled to establish business enterprises. The survey study used the primary instrument of the questionnaire and data collected were analysed using rank order. The results revealed that earning extra money, social status, etc. were factors that motivated women to become entrepreneurs.

A study by Patterson and Mavin (2009) examined women entrepreneurs: jumping the corporate ship or gaining new wing. The objective of this research was to explore how women leaving full-time employment to start up business make sense of their experience in relation to their career transition and the post-career transition effects. The study was an exploratory study; data were gathered from the four female entrepreneurs from the service sector and a director of a local enterprises support organisation. The findings revealed that the original motivation for venturing into entrepreneur was not necessarily satisfied by the career transition; however, as the female entrepreneurs' businesses evolved, the personal and professional development they underwent superseded any concerns they might have had regarding their original motivation giving them new wings.

\subsection{Theoretical Framework}

The present study is based on Holland's (1997) theory as cited in Yilmaz (2017). There are mainly four primary assumptions of Holland's theory:

a) in the socio-cultural environment, persons can be categories as one of the following: realistic, investigating, artistic, social, enterprising or conventional;

b) there are six modal environments: realistic, investigating, artistic, social, enterprising or conventional;

c) people search for environments that will let them exercise their skills and abilities, express their attitudes and values and take on agreeable problems;

d) roles are determined by an interaction between personality and environment. 
The theory, therefore, proposes that people are attracted to work in the environments that conform to their personality orientation. Holland refers to the alignment between personality and work environment, as congruence. He proposes that individuals whose personalities are poorly matched to their work environments are more likely to change career than their congruent counterparts. The theory is very vital for voluntary career transiting women from organisational paid work to entrepreneurship. The theory suggests that people will only engage in entrepreneurship if they believe they have the skill to exploit the opportunities. The woman entrepreneur must have discovered her personality type and the suitable environment she belongs to in the course of relating and working with others. These are the very important factors to be considered before embarking on transition so as to remain successful in business. The transition and choice of business must have a fit for the woman to be successful.

\subsection{The Relatedness to the Study and Managerial Implications of the Theory}

Holland's theory implies that the personality type can be developed through constant participation in the organisational activity, which would eventually give rise to person's interest and competencies that would create a particular personal disposition to perceive or develop an entrepreneurial mind-set. Competencies can also be achieved through personal forces such as peers, parents, social class, culture and the physical environment. Organisational management should, therefore, encourage group or teamwork.

\section{METHODOLOGY}

\subsection{Data Collection and Sample Characteristics}

There are 3,224,324 micro businesses in Lagos state according to SMEDAN and the National Bureau of Statistic Collaborative Survey: Selected Findings (2013). However, neither the total number of women-owned micro businesses nor women micro business owners who are formal employees of an organisation is known. Moreover, the union list of this market is salient about the nature and size of the business. Therefore, in order to avoid being based on the population and sample size, the research used Topman's formula to determine the appropriate population.

$$
N=\frac{Z^{2} * P * q}{E^{2}}
$$

Where $N$ is the sample population for women micro business owners, $z=(1.96), p$ is the probability of positive response $(0.5), q$ is the probability of negative response (0.5), $E$ is the amount of error that can be allowed (0.05). It is important to note that infinite population is only determined based on the circumstances and conveniences taking into consideration time, cost and precision of reaching the women micro business owners. Using inferential judgment and conveniences, $P$ will be represented with $(0.5)$ while $q$ will be represented with (0.5). We have: $N=\left(1.96^{2} * 0.5 * 0.5\right) / 0.05^{2}=384.16$ approximately. 
From this calculated population, 250 are randomly selected as the sample size (n). Average distribution was used to select the number of questionnaires that should be distributed in the selected lines of business. This is to ensure a fair collection of data. The formula for this is:

$$
X=n / k
$$

Hence, $X=250 / 10, X=25$ questionnaires in each of the ten selected lines. $X$ is the sample size to be distributed in each line, $n$ is the sample size (250) and $k$ is the number of the selected lines.

The Balogun market is comprised of different streets and different sections, e.g., baby clothing, Mandela, Adure, Jewelleries line, Provisions line etc. The researcher randomly selected ten lines out of the numerous lines of businesses due to time and convenience. Out of the two hundred (250) questionnaires shared with these groups, one hundred and four (104) were considered suitable for this study. Frequencies, percentages and descriptive statistics of sum, mean, standard deviation (Std. Dev.) and variance were used to analyse questionnaire items, while the hypotheses were tested using a linear regression analysis of SPSS 23.

\subsection{Measurement Scale, Validity and Reliability Test}

The area of the carrier transitions involved in this study does not permit the use of already existing measurement scale. This is because it is a new area in carrier development literature as such it lacks the previous measurement scale. The study, therefore, employed self-constructed questionnaire items to measure the independent variable of 'career transition'. The firm growth was assessed from the previously used measurement scale of Neneh and Vanzyl (2014) modified to suit the study. The researcher used an interview to sort out those who had worked at an organisation before. Other useful information was received through the instrument of questionnaire so as to guide in searching out this particular group of formal employees (those who voluntarily resigned or retired). Likert's 3-point scale was used in the questionnaire, which included $1=$ Agree, $2=$ Disagree and $3=$ Undecided. The questionnaire item consisted of 17 questions, six questions for testing the independent variable of voluntary carrier transitions (voluntary resignation and voluntary retirement), while 11 questions were used to test the dependent variables.

Table1. Reliability Test for Variables using Cronbach Alpha (made by the author)

\begin{tabular}{|l|c|c|c|c|c|c|c|}
\hline \multicolumn{1}{|c|}{ Variables } & $\begin{array}{c}\text { Number } \\
\text { of items }\end{array}$ & $\begin{array}{c}\text { Scale } \\
\text { formatted }\end{array}$ & $\begin{array}{c}\text { \% } \\
\text { Variance }\end{array}$ & $\begin{array}{c}\text { Cumulative } \\
\text { \% }\end{array}$ & $\begin{array}{c}\text { Cronbach's } \\
\text { Alpha }\end{array}$ & CR & AVE \\
\hline $\begin{array}{l}\text { Voluntary career } \\
\text { transition }\end{array}$ & 6 & LRF & 1579.82 & 1579.826 & 0.963 & 0.91 & 0.56 \\
\hline $\begin{array}{l}\text { Number of } \\
\text { employees employed }\end{array}$ & 4 & LRF & 1650.11 & 3229.945 & 0.963 & 0.90 & 0.60 \\
\hline Asset growth & 3 & LRF & 1565.67 & 4795.623 & 0.964 & 0.93 & 0.75 \\
\hline Sales growth & 3 & LRF & 1565.77 & 6361.401 & 0.963 & 0.94 & 0.90 \\
\hline
\end{tabular}

The Table 1 shows the reliability and validity test. 
The items of the questionnaire were subjected to a confirmatory factor analysis (CFA) to ascertain the validity and reliability test. The items were individually loaded in order to evaluate their critical ratio range. The critical values adopted were from 0.70 to 0.90 , which was above the suggested threshold of 0.50 and above (Hair, Sarstedt, Ringle \& Mena, 2012). The composite reliability (CR) values were 0.90 and higher and the alpha values were also higher than the threshold of 0.70 . The table shows that the internal consistency reliability was adequate. The study controlled firm age and the number of paid employees. The firms used had been in existence for the past five years and also had paid employees. This was to ensure uniformity of the sample firms used.

Table 2. Respondents' Distribution of Questionnaires based on Business Line (made by the author)

\begin{tabular}{|l|c|c|c|c|c|}
\hline \multicolumn{1}{|c|}{ Business line } & $\begin{array}{c}\text { No. Not } \\
\text { Returned }\end{array}$ & $\begin{array}{c}\text { No. Not } \\
\text { used }\end{array}$ & Not used & $\begin{array}{c}\text { Frequency } \\
\text { of used }\end{array}$ & Percent \\
\hline Babies & 9 & 3 & 13 & 13 & 12.5 \\
\hline Provision & 12 & 2 & 11 & 11 & 10.6 \\
\hline Wrapper (Ankara) & 7 & 8 & 10 & 10 & 9.6 \\
\hline Jewelleries & 8 & 5 & 12 & 12 & 11.5 \\
\hline Fashion (Cloth) & 8 & 5 & 12 & 12 & 11.5 \\
\hline Stationeries & 13 & 4 & 8 & 8 & 7.7 \\
\hline Articles & 10 & 8 & 7 & 7 & 6.8 \\
\hline Shoes and Bag & 9 & 3 & 13 & 13 & 12.5 \\
\hline Household Equipment & 9 & 8 & 8 & 8 & 7.7 \\
\hline Cosmetics & 10 & 5 & 10 & 10 & 9.6 \\
\hline Total & 95 & 51 & 104 & 104 & 100 \\
\hline
\end{tabular}

Table 2 above shows the respondents' distribution of questionnaires based on business line, the women specialising in shoes and bag and babies lines responded more followed by jewellery and fashion lines.

\section{DATA ANALYSIS}

\subsection{Analysis of Biographical Data of the Respondents}

The analysis showed that out of the 104 respondents 43 were of age between 41-50 years representing $41.3 \%$; 37 respondents were of age $31-40$ years representing $35.6 \%$; respondents that were less than 30 years of age were 8 representing $7.7 \%$ of the total respondents, while 6 respondents $(5.8 \%)$ were at the age of 51-60. Ten $(9.6 \%)$ respondents were at the age of 61 years and above. The marital status showed that $61(58.7 \%)$ respondents were married, while $12(11.5 \%)$ respondents were single and $20(19.2 \%)$ respondents were divorced. However, 11 $(10.6 \%)$ respondents were widowed. The number of married respondents was greater $\%$ and hence this suggested that family-related problems could be one of the main reasons of transiting to self-employment. 
The analysis also showed the working experience in the formal organisation in years: $11(10.6 \%)$ respondents had $1-5$ years of working experience, $44(42.3 \%)$ respondents had 6-10 years of working experience, $31(29.8 \%)$ respondents had 11-15 years of working experience, $10(9.6 \%)$ respondents had 16-20 years of working experience and $8(7.7 \%)$ respondents had 21 years and above of working experience. The analysis showed that the experience of 6-15 years indicated that these respondents had gathered enough competencies, skills, and knowledge. However, this depends on the type of work and level of involvement in the work as the majority of the respondents did not represent the managerial cadre. The more exposure employees have the more experience they gather.

Respondents' educational qualification revealed that 30 (28.8\%) respondents had only SSCE/GCE certificates, 4 (3.8\%) respondents had a PhD. degree. Ten $(9.6 \%)$ respondents had Master's degree and professional qualification, while 21 $(20.2 \%)$ respondents had first degree and $39(37.5 \%)$ respondents had OND/NCE certificates. Respondents' status in the formal organisation from the table above shows that the numbers of women at the management level before transiting was $12(11.5 \%)$ respondents. The middle-level positions were occupied by $49(47.1 \%)$ respondents, while the junior staff was represented by 43 respondents. Voluntary resignation or retirement analysis indicated that $71(68.3 \%)$ respondents voluntarily resigned, while 33 respondents resigned.

\subsection{Response Data Relating to the Main Variables of Voluntary Transition}

According to the results of the analysis from Table 3 below, Q1 above indicates that a majority of the respondents ascertain that they have been operating their business as part-time before voluntarily retire/resign. This is clearly visible from the responses given to Q1 as 92 respondents out of the total of 104 with the mean of 1.1827 and standard deviation 0.53543 agreed, although 5 respondents disagreed to this whereas 7 respondents were indifferent to it. The Q2 in Table 3 reveals that the knowledge gained from formal organisations exposed the respondents to the opportunities that led them to either voluntarily resigned or retired as 81 respondents support the opinion, 11 respondents disagreed to it while 12 are indifferent on the statement. Also, the descriptive statistics showed the sum of 139.00, mean of 1.3365 and standard deviation of 0.67710 .

Table 3. Analysis of Data on Independent Variables (X) (made by the author)

\begin{tabular}{|l|c|c|c|c|c|c|c|}
\hline Variables & \multicolumn{3}{|c|}{ Frequencies \& (Percentages) } & \multicolumn{4}{c|}{ Descriptive statistics } \\
\hline Items & $A G$ & $D A$ & $U D$ & SUM & MEAN & $S D$ & VAR \\
\hline Q1 & $92(88.5)$ & $5(4.8)$ & $7(6.7)$ & 123.00 & 1.1827 & 0.53543 & 0.287 \\
\hline Q2 & $81(77.9)$ & $11(10.6)$ & $12(11.5)$ & 139.00 & 1.3365 & 0.67710 & 0.458 \\
\hline Q3 & $87(83.7)$ & $8(7.7)$ & $9(8.7)$ & 130.00 & 1.2500 & 0.60339 & 0.364 \\
\hline Q4 & $90(86.5)$ & $6(5.8)$ & $8(7.7)$ & 126.00 & 1.2115 & 0.56899 & 0.324 \\
\hline Q5 & $74(71.2)$ & $14(13.5)$ & $16(15.4)$ & 150.00 & 1.4423 & 0.74816 & 0.560 \\
\hline Q6 & $80(76.9)$ & $15(14.4)$ & $9(8.7)$ & 137.00 & 1.3173 & 0.62728 & 0.393 \\
\hline
\end{tabular}


However, there was a strong support for Q3 as 87 respondents supported this view; 8 respondents did not seem to support it, while 9 were sceptical of whether they acquired enough experience, skills, knowledge, and competence from their formal organisation before voluntarily retirement/resignation. This had the sum of 130.00 and men of 1.2500. In the same vein, there was also strong support for Q4 as 90 respondents supported this view, 6 respondents did not seem to support it while 8 were doubtful of whether voluntarily retirement/resignation helped them to capitalise the discovered opportunities. This had the mean of 1.2115 and standard deviation of 0.56899 . A greater number of respondents; (74 out of a total of 104) reveal their readiness to embark in micro businesses before transiting as suggested in Q5 of Table 3.

However, 14 respondents dispute this while 16 were not sure of whether they are ready before transiting or not. This had the highest sum and means of 150.00 and 1.4423 , respectively. This suggested that there might be different reasons for the transition. Campbell (2012) notes that some transit to self-employment due to health-related issues. Thus, according to Q6, most women entrepreneurs were involved in paid work to gather capital for their business. 80 respondents support this; 15 disagreed with it, while 9 were unconvinced and their descriptive statistic showed the sum of 137.0, mean of 1.3173 and standard deviation of 0.62728 .

\subsection{Response Data Relating to the Main Variables of Firm Growth}

According to the results of the analysis from Table 4, the Q7 above indicates that a majority of the respondents ascertained that they intended to grow their businesses before voluntarily reassignment/retirement. This is clearly visible from the responses given in Table 4, Q7, where 97 respondents out of the total of 104 respondents agreed, although 4 respondents disagreed, whereas 3 respondents were not so sure about it.

Table 4. Analysis of Data on Dependent Variables (Y) (made by the author)

\begin{tabular}{|l|l|l|l|l|l|l|l|}
\hline Variables & \multicolumn{3}{|c|}{ Frequencies \& (Percentages) } & \multicolumn{4}{c|}{ Descriptive statistics } \\
\hline Items & $A G$ & $D A$ & $U D$ & SUM & MEAN & $S D$ & VAR \\
\hline Q7 & $97(93.3)$ & $4(3.8)$ & $3(2.9)$ & 114.0 & 1.0962 & 0.38211 & 0.146 \\
\hline Q8 & $90(86.5)$ & $7(6.7)$ & $7(6.7)$ & 125.0 & 1.2019 & 0.54648 & 0.299 \\
\hline Q9 & $100(96.2)$ & 0.000 & $4(3.8)$ & 118.0 & 1.1346. & 0.50353 & 0.254 \\
\hline Q10 & $74(71.2)$ & $14(13.5)$ & $16(15.4)$ & 112.0 & 1.0769 & 0.38648 & 1.149 \\
\hline Q11 & $97(93.3)$ & 0.000 & $7(6.7)$ & 235.0 & 2.2596 & 1.23064 & 1.514 \\
\hline Q12 & $80(76.9)$ & $15(14.4)$ & $9(8.7)$ & 230.0 & 2.2115 & 1.31955 & 1.741 \\
\hline Q13 & $58(55.8)$ & $22(21.2)$ & $24(23.1)$ & 577.0 & 5.5481 & 2.54619 & 6.483 \\
\hline Q14 & $65(62.5)$ & $15(14.4)$ & $24(23.1)$ & 126.0 & 1.2115 & 0.56899 & 0.324 \\
\hline Q15 & $90(86.5)$ & $6(5.8)$ & $8(7.7)$ & 150.0 & 1.4423 & 0.74816 & 0.560 \\
\hline Q16 & $80(76.9)$ & $15(14.4)$ & $9(8.7)$ & 137.0 & 1.3173 & 0.62728 & 0.393 \\
\hline Q17 & $87(83.7)$ & $8(7.7)$ & $9(8.7)$ & 130.0 & 1.2500 & 0.60339 & 0.364 \\
\hline
\end{tabular}


This gives Q7 in the descriptive statistics the sum of 114.00 , mean of 1.0962 and standard deviation of 0.38211 . The voluntary retirees and resigned employees also reacted to the questionnaire tool of Q8 agreeing that their sales volume increased since they voluntarily resigned/retired with 90 respondents supporting the opinion, 7 respondents disagreed with it while 7 could not say whether their sale had increased or not; therefore, the sum of this was 125.00 , while the mean was 1.2019 and standard deviation was 0.54648 . However, there is a strong support for Q9 confirming that they felt they were competent and fulfilling in their business before resignation/retirement as 74 respondents supported this view, 14 disagreed with this, while 16 were sceptical about it; therefore, having the sum of 118.00 , mean of 1.1346 and standard deviation of 0.50353 . In the same manner, there is also a strong support for Q10 as 74 respondents were in support of this view and 14 respondents disagreed with it; however, 16 were doubtful of whether the number of their customers increased. This has the descriptive statistic of sum 112.00, mean 1.0769 and standard deviation of 0.38648. Q11 suggested that the number of assets from their business' proceeds increased since they voluntarily resigned/retired as 97 agreed with it; none disagreed with it and 7 were undecided. This has the sum of 235.00, mean of 2.2596 and standard deviation of 1.23064. Thus, also Q12 suggested that most women entrepreneurs expanded their businesses to other areas as 80 respondent supported this view, 15 disagreed with it, while 9 were unconvinced having the sum of 230.00 , mean of 2.2115 and standard deviation of 1.31955 .

Furthermore, Q13 suggested that most women entrepreneurs operated their businesses with the paid employee as 58 respondents supported this view, 22 disagreed with it, while 24 were unconvinced. It had the sum of 577.00, mean of 5.5481 and 2.54619. In Q14, 65 agreed that the number of their paid employees increased since they voluntarily resigned/retired as 15 respondents agreed with this views, although 24 did not seem to agree while 4 were not too sure about this. It had the sum of 126.00 , mean of 1.2115 and standard deviation of 0.56899 . In the same vein, Q15 suggested that they found their business activities well suited to their abilities as 90 respondents supported this view, 6 disagreed with it, while 8 were unconvinced. It had the sum of 150.00 , mean of 1.4423 and 74816 . Thus, also Q16 suggested that they were innovative in their business, seeking out new ways of improving their business as 80 respondents supported this view, 15 disagreed with it, while 9 were unconvinced. It had the sum of 137.0, mean of 1.3173 and standard deviation of 0.62728 . Moreover, the response from Q17 suggested that 87 respondents were not afraid to commit money and resources to new products and projects while 8 respondents were afraid and 9 were undecided. This has the sum of 130.00 , mean of 1.2500 and standard deviation of 0.60339 .

\section{ANALYSIS OF THE HYPOTHESES}

\section{Research Hypotheses}

Ho1: voluntary career transition positively affects the number of employees employed by the business under study 
Ho2: voluntary career transition positively affects sales' growth of the business under study

H03: voluntary career transition positively affects assets' growth of the business under study

Table 5 shows the results of the multiple analyses on the relationship between voluntary career transition and employment creation, sales' growth and asset' increase.

Table 5. Model Summary of the Relationship between Dependent and Independent Variables (made by the author)

\begin{tabular}{|c|c|c|c|c|c|c|c|c|c|}
\hline \multirow{2}{*}{$\begin{array}{c}\text { Variab- } \\
\text { les }\end{array}$} & \multirow[t]{2}{*}{$R$} & \multirow[t]{2}{*}{$R^{2}$} & \multirow{2}{*}{$\begin{array}{l}\text { Adjus- } \\
\text { ted } R^{2}\end{array}$} & \multirow{2}{*}{$\begin{array}{c}\text { Std. } \\
\text { error } \\
\text { estimate }\end{array}$} & \multicolumn{5}{|c|}{ Change statistics } \\
\hline & & & & & $\begin{array}{c}R^{2} \\
\text { change }\end{array}$ & $\begin{array}{c}F \\
\text { change }\end{array}$ & df & $d f^{2}$ & $\begin{array}{l}\text { Sig. } F \\
\text { change }\end{array}$ \\
\hline $\begin{array}{l}\text { Emp- } \\
\text { loyment }\end{array}$ & 0.953 & 0.907 & 0.907 & 0.47808 & 0.907 & 1000.1 & 1 & 102 & 0.00 \\
\hline $\begin{array}{l}\text { Sales } \\
\text { increase }\end{array}$ & 0.766 & 0.587 & 0.583 & 3.2874 & 0.587 & 145.15 & 1 & 102 & 0.00 \\
\hline $\begin{array}{l}\text { Asset } \\
\text { increase }\end{array}$ & 0.399 & 0.160 & 0.151 & 1.1082 & 0.160 & 19.35 & 1 & 102 & 0.00 \\
\hline
\end{tabular}

Predictors: (Constant), Voluntary Career Transition

The correlation value indicates $(r=0.953$ at $p=0.00)$ employment generation and $(r=0.766$ at $p=0.00)$ sales increase, while asset increase has $(r=0.399$ at $p=0.00)$. However, the coefficient of determination $R^{2}$ value 0.907 implies that $90.7 \%$ variance of employment creation of the business can be explained by voluntary career transition while that of sales' growth is $58.7 \%$ and asset' increase has a very low coefficient of determination $R^{2}$ of 0.106 causing only about $10 \%$ of the variance.

Table 6. ANOVA of the Relationship between Dependent and Independent

Variables (made by the author)

\begin{tabular}{|l|l|c|c|c|c|c|}
\hline \multicolumn{2}{|c|}{ Model } & Sum of squares & Df & Mean square & $\boldsymbol{F}$ & Sig. \\
\hline \multirow{3}{*}{$\begin{array}{l}\text { a. Employment } \\
\text { generation }\end{array}$} & Regression & 228.601 & 1 & 228.601 & 1000.19 & $0.000 \mathrm{~b}$ \\
\cline { 2 - 8 } & Residual & 23.313 & 102 & 0.229 & & \\
\cline { 2 - 8 } & Total & 251.913 & 103 & & & \\
\hline \multirow{5}{*}{ b. Sales' increase } & Regression & 1568.714 & 1 & 1568.714 & 145.156 & $0.000 \mathrm{~b}$ \\
\cline { 2 - 8 } & Residual & 1102.324 & 102 & 10.807 & & \\
\cline { 2 - 8 } & Total & 2671.038 & 103 & & & \\
\hline \multirow{5}{*}{ c. Asset' increase } & Regression & 23.772 & 1 & 23.772 & 19.357 & $0.000 \mathrm{~b}$ \\
\cline { 2 - 8 } & Residual & 125.266 & 102 & 1.228 & & \\
\cline { 2 - 8 } & Total & 149.038 & 103 & & & \\
\hline
\end{tabular}

b. Predictors: (Constant), Voluntary Career Transition

The ANOVA (in Table 6 above) further reveals that the relationship is significant at $95 \%$ confidence level, the variable produces statistical values with a positive level of $p=(0.00)$. If the $\mathrm{f}$-value is equal or greater than sig value there 
is a significant effect, we reject the null hypotheses and uphold the alternative hypotheses. Here, (1000.191, 145.156 and $19.357>0.000 \mathrm{~b})$ respectively. We, therefore, reject the null hypotheses and uphold the alternatives.

Table 7. The Coefficients of the Relationship between Dependent and Independent Variables (made by the author)

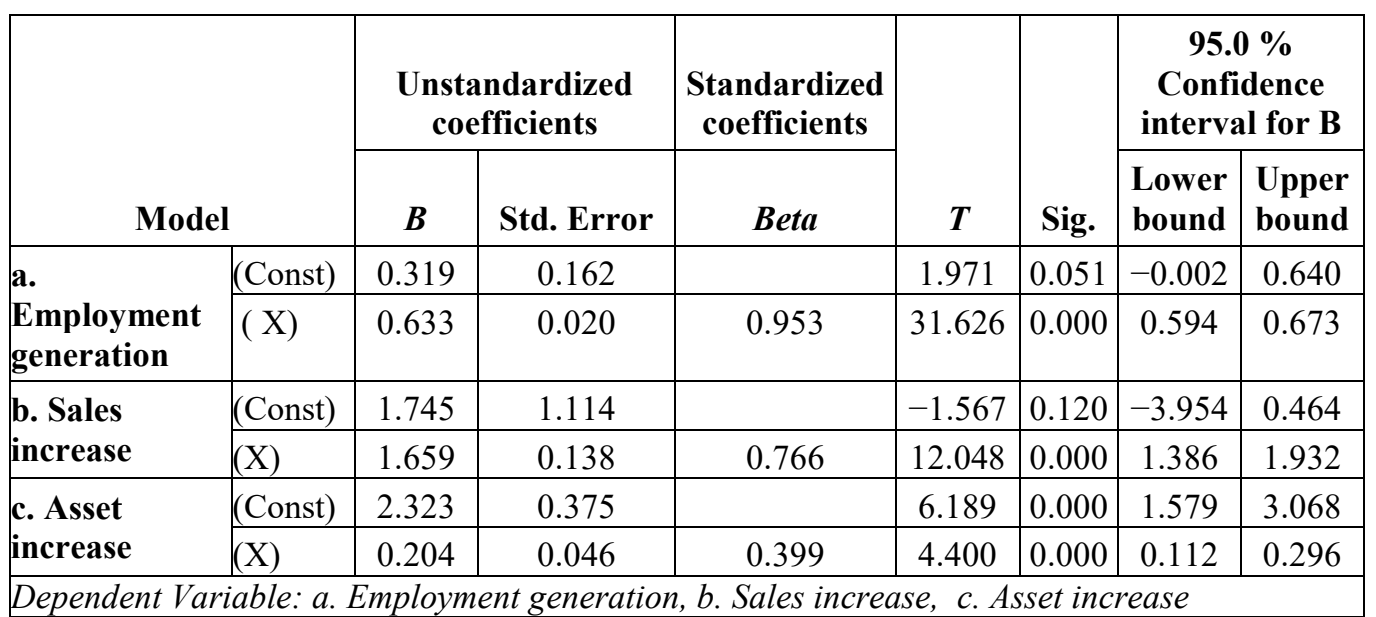

Table 7 demonstrates that voluntary career transition has a very strong positive effect on the employment creation of the business under study as the constant has (Beta 0.633 and $t=31.626$ ). This shows that employment creation is 0.953 at $p<0.00$. The estimated regression line is $Y=0.319+0.633 X$, which implies that if $X=0$, then $Y$ will be 0.319 and with $1 \%$ increase in $X$, there will be an increase of 0.633 in $Y$. The coefficient depicts the results regarding the strength of the variable (employment generation) used for the study.

The table displays that voluntary career transition has a positive effect on the sales' growth of the business under study with (Beta $=1.659$ and $t=12.048)$. This shows that sales growth is 0.766 at $p<0.00$. The estimated regression line is $Y=1.745+1.659 X$, which implies that if $X=0$, then $Y$ will be 1.745 and with $1 \%$ increase in $X$, there will be an increase of 1.659 in $Y$. The coefficient depicts the results regarding the strength of the variable (sales growth) used for the study.

The table also shows that voluntary career transition has a positive effect on the asset increase of the business under study with $($ Beta $=0.204$ and $t=4.400)$. This shows that asset increase is 0.399 at $p<0.00$. The estimated regression line is $Y=2.323+0.204 X$, which implies that if $X=0$, then $Y$ will be 2.323 and with $1 \%$ increase in $X$, there will be an increase of 0.204 in $Y$. The coefficient depicts the results regarding the very low strength of the variable (asset increase) used for the study.

\section{DISCUSSION AND IMPLICATION OF THE FINDINGS}

The findings of the present study are based on a survey questionnaire completed by women micro business owners in selected business lines at Balogun market. The results reveal that women who transit to self-employment from paid organisations 
have the intention to develop their businesses. This decision affects the number of paid employees they engage, the daily sales increase of their businesses and the asset increase they acquire. The model summary shows that voluntary career transition has a very high positive effect on the employment generation, a high positive effect on the sales growth and a very low positive effect on the asset growth of the business.

Voluntarily retirees and resigned women, therefore, develop their businesses rapidly. This is not surprising as the previous organisational knowledge and competencies acquired assist them in using business opportunities in their environment.

Asset increase is less affected by women who undertake the voluntary transition to self-employment, retail businesses as used in the study. The following factors can contribute to this situation: the business needs a huge capital to buy varieties and stock goods in order to satisfy customers and to maintain the business. It is then easy for a civil servant or an employee to invest their salary in assets than for a selfemployed businesswoman. From the questionnaire respondents, we can infer that these women employ and motivate their employees being employees themselves. They know what it takes to be good managers.

The questionnaire also reveals that women with high educational qualification have more opportunities to find jobs with better salary that might not enable them to transit to self-employment unless, after retirement. As a result, only a few women in the top management transit while women in the middle of managerial hierarchy transit more than the women in top management and at the junior level. Further research can be carried out to find out the reasons of this situation. This shows that a majority of educated women do not like to be self-employed (UNCTAD, 2014). According to Norman (2012), a high educational level has a positive impact on profitability.

From the data collected, it can be stated that a greater number of women who transit are still women within the active years of service. This is in agreement with the finding of Lachman, Teshale and Agrigoraei (2015) that women tend to transit in their middle age. This shows that those who transit from formal organisations to self-employment do so at an early age of their working years.

The years of experience matter a lot in this study; it reveals the competencies these women that transit has. Hall and Suddarth (2015) and Lachman, Teshale and Agrigoraei (2015) argue that it is very difficult, therefore, to sack experienced employees; rather they easily transit to other jobs or self-employed job. Although there might be many reasons, from Table 3 it can be seen that married women prevail, suggesting that family-related issues could be one of the reasons for transition to self-employment.

\section{CONCLUSION}

Increasing attention has been devoted to micro businesses of the informal sectors and women entrepreneurship as a study of OECD (2016) observes that women are more likely than men to quit paid employment to self-employment. However, there is lack of empirical conclusions on how the previous knowledge 
acquired from formal organizations can contribute to the business growth of a selfemployed woman that transit to micro business. The general conclusion is that these firms lack growth (Gupta, Guha \& Krishnaswami, 2013), especially when it is a woman-owned business. There is a lack of literature on the effects or relationship between voluntary career transition and firm growth. The findings have indicated that voluntary carrier transition of the resigned and retired women from paid employment to self-employment moderately contribute to the growth of their businesses through the increased employment of the paid staff, increased sales and increased assets. Women micro businesses, therefore, improve the economic and social opportunities, and the generation of employment thereby contributes to poverty reduction in the country.

It can be concluded that women micro-businesses may be unattractive in the short term to help family juggle work, but can be a costly long-term investment choice for women as a means of salary support, pension, and retirement entitlements, saving and job security through its high employment generation and sales increase if they voluntarily resigned from their jobs or retired. Voluntary career transition moderately affects the growth of women micro businesses at Balogun Market, Lagos State. This study concludes that voluntary career transition positively affects the growth of women-owned businesses. According to the findings, voluntary career transition has a strong positive relationship with employment generation, a positive relationship with sales increase and a weak positive relationship with assets increase. This is inconsistent with previous findings of the OECD (2016). The paper has revealed that the decision to quit voluntarily from paid employment and to transit to self-employment signifies high intention to develop a business. It, therefore, reaffirms that the intention for starting business matters a lot for the business to grow while suggesting that not all womenowned businesses lack growth.

Based on the findings, the following recommendations have been made:

1) Organisational management should encourage intrapreneurship attitude between an organisational manager and staff as it is an important ingredient in the process of developing growing SMEs and this can be achieved through increasing responsibilities, engagement and the recognition of staff.

2) Government policies should focus on assisting people to consider entrepreneurship as a valid career choice and as the pursuit of opportunities rather than the solution to unemployment.

\section{LIMITATIONS OF THE STUDY}

The greatest limitations of the present study are based on the sample size. Due to difficulty related to involving women micro business owners who are formal employees of the organisation, the sample size was limited. The subsequent research is encouraged therefore to expand the scope of the study in order to increase the sample size. Another limitation is based on the subjective method of data gathering that might result in a biased result. Subsequent research should be more objective to gather more unbiased data. 


\section{ACKNOWLEDGMENT}

I sincerely acknowledge my supervisor Dr. Udu, Ama A. for his contribution to the present research. I will forever remain grateful to my academic mentor whose absolute support and encouragement is like a motivating force against all odds for me throughout the period of this study: Professor Oye, IbidapoObe, and former Vice-Chancellor of the University of Lagos, Akoka, Lagos State and pioneer ViceChancellor, AE-Federal University Ndufu-Alike Ikwo, Ebonyi State, Nigeria. I am also indebted to Professor Oladele Caleb Orimuoogunje of the Department of Linguistics, African and Asian Studies, Faculty of Arts, UNILAG for making necessary corrections and proposing valuable suggestions regarding the present research. My sincere appreciation also goes to Professor K.R. Ojukutu Formal Dean, Faculty of Management Sciences UNILAG, for teaching me the statistical package of social sciences that made this work easy. I would not have found the present research easy if there were not the wonderful financial support from MEI GROUP LTD, Lagos, Nigeria, which I sincerely appreciate.

\section{REFERENCES}

Blumberg, B., \& Pfann, G. (2016). Roads Leading to Self-Employment: Comparing Trans-Generational Entrepreneurs and Self-Made Start-Ups. Entrepreneurship Theory and Practice, 40(2) 335-357. https://doi.org/10.1111/etap.12227

Campbell, B.A. (2012). Earnings Effects of Entrepreneurial Experience: Evidence from the Semiconductor Industry. Management Science, 59(2), 286-304. https://doi.org/10.1287/mnsc.1120.1593

Chen, L., \& Thompson, P. (2016). Skill Balance and Entrepreneurship: Evidence from Online Career Histories. Entrepreneurship. Theory and Practice, 40(2), 289-305. https://doi.org/10.1111/etap.12220

Dingemans, E., \& Henkens, K. (2014). Involuntary Retirement, Bridge Employment, and Satisfaction with Life: A Longitudinal Investigation. Journal of Organizational Behaviour, 35(4), 575-591. https://doi.org/10.1002/job.1914

Duberley, J., Carmichael, F., \& Szmigin, I. (2014). Exploring Women's Retirement: Continuity, Context, and Career Transition. Gender, Work and Organization, 21(1), 71-90. https://doi.org/10.1111/gwao.12013

Ebitu, E. T., Basil, G., \& Ufot, J. A. (2016). An Appraisal of Nigeria's Micro, Small and Medium Enterprises (MSMEs): Growth, Challenges, and Prospects. International Journal of Business and Entrepreneurship Research, 4(4), 1-15. Retrieved from http://www.eajournals.org/wp-content/uploads/An-Appraisal-ofNigeria\%E2\%80\%99s-Micro-Small-and-Medium-Enterprises-MSMES-Growth-Challenges-andProspects.pdf

Grigore, A.M., \& Toma, S. G. (2014). Perceptions of Entrepreneurship a Career Path. Proceedings of the 8th International Management Conference; Management Challenges for Sustainable Development, November 6-7, 2014, Bucharest, Romania 153-165. Retrieved from http://conferinta.management.ase.ro/archives/2014/pdf/14.pdf

Gupta, P.D, Guha, S. \& Krishnaswami, S. S. (2013). Firm Growth and its Determinants. Journal of Innovation and Entrepreneurship, 2(15), 1-14. https://doi.org/10.1186/2192-5372-2-15

Hair, J. F., Sarstedt, M., Ringle, C. M., \& Mena, J. A. (2012). An Assessment of the Use of Partial Least Squares Structural Equation Modelling in Marketing Research. Journal of the Academy of Marketing Science, 40(3), 414-433. https://doi.org/10.1007/s11747-011-0261-6

Hall, M. E., \& Suddarth, B. H. (2015). Facilitating Midcareer Transitions. In P.J. Hartung, M.L. Savickas and W.B. Walsh (Eds.). APA Handbook of Career Intervention: vol.2. Applications (pp. 495-505). Washington, DC: American Psychological Association.

Lachman, M. E., Teshale, S., \& Agrigoroaei, S. (2015). Midlife as a Pivotal Period in the Life Course: Balancing Growth and Decline at the Crossroads of Youth and Old Age. International Journal of Behavioral Development, 39(1), 20-31. https://doi.org/10.1177/0165025414533223

Murphy, D.D. (2017). A Model of Women Entrepreneurs' Well-being. Theses and Dissertations. Presented to University of Wisconsin Milwaukee Lubar School of Business. Retrieved October, 2017, from http://dc.uwm.edu/etd/1516

National Bureau of Statistic (2013). Micro, Small and Medium Enterprises National Survey. Retrieved February, 2017, from http://www.nigerianstat.gov.ng/pdfuploads/MSME\%20Presentation.pdf

Neneh, B.N., \& Vanzyl, J. (2014). Growth Intention and Its Impact on Business Growth amongst SMEs in South Africa. Mediterranean Journal of Social Sciences, 5(20), 172-163. https://doi.org/10.5901/mjss.2014.v5n20p172

Norman, C. (2012). Impact of Level of Education and Experience on Profitability of Small Grocery Shops in South Africa. International Journal of Business Management and Economic Research, 3(1), 462-470. Retrieved from http://ijbmer.com/docs/volumes/vol3issue1/ijbmer2012030110.pdf 
Nzewi, H. N., Onwuka, E. M., \& Onyesom, M. (2017). Entrepreneurship Evolution and the Growth of Small Scale Businesses in Nigeria. Journal of Business and Economic Development, 2(3), 176-181. https://doi.org/10.11648/j.jbed.20170203.16

Obunike, C.F. (2016a). Organizational Innovation and Performance: A Study of Women Small Scale Industries in Mammy Market, Ojo, Lagos, Nigeria. Nigeria. Journal of Business, 7(1), 90-103.

Obunike, C.F. (2016b). Entrepreneurship, Small Scale Enterprises and Employment Creation in Ebonyi. JORIND, 14(2), 1-9. Retrieved November, 2017, from www.ajol.info/journals/jorind

Obunike, C.F. (2018). Comparative Analysis of Socio-Cultural Dichotomy of and Entrepreneurial Performance; A Study of Women-Owned Micro Enterprises in Lagos, Nigeria. Osogbo Journal of Management (OJM), 3(1), 23-38.

Organization for Economic Corporation and Development (OECD). (2016). Gender Equality in Education, Employment and Entrepreneurship: Meeting of the OECD Council at Ministerial Level Paris; www.oecd.org/social/family/50423364.

Organization for Economic Cooperation and Development (OECD). (2017). Small, Medium, Strong. Trends in SME Performance and Business Conditions, OECD Publishing, Paris. http://www.oecd.org/ 9789264275683-en.htm

Patterson, N., \& Mavin, S. (2009). Women Entrepreneurs: Jumping the Corporate Ship or Gaining New Wings. International Small Business Journal: Researching Entrepreneurship, 27(2), 173-192. https://doi.org/10.1177/0266242608100489

Sanzenbacher, G. T., Sass, S.A., \& Gillis, G.M. (2017). The Effect of Job Mobility on Retirement Timing by Education. Working Paper 2016-17. Chestnut Hill, MA: Center for Retirement Research at Boston College.

Sarwoko E., Surachman, A., \& Hadiwidjojo, D. (2013). Entrepreneurial Characteristics and Competency as Determinants of Business Performance in SMEs, IOSR Journal of Business and Management, 7(3), 31-38. Retrieved from http://www.iosrjournals.org/iosr-jbm/papers/Vol7-issue3/E0733138.pdf

Serazul, I. (2012). Pull and Push Factors towards Women Small Entrepreneurship Development in Bangladesh, Journal of Research in International Business Management, 2(3), 065-072. Retrieved from https:/www.scribd.com/document/363975752/Pull-and-Push-Factors-Towards-Small-EntrepreneurshipDevelopment-in-Bangladesh

Srivastava, A. (2017). Women Entrepreneurship and Education, Voice of Research, 5(4), 28-31. Retrieved from http://www.voiceofresearch.org/doc/Mar-2017/Mar-2017_10.pdf

United Nations Conference on Trade and Development (UNCTAD). (2014). Empowering Women Entrepreneurs through Information and Communications Technologies a Practical Guide, N9 Working Paper

Yilmaz, O. (2017) cited Holland's (1997) in “An Evidence for Validity of Holland's Theory of Personality Types in Turkish Culture ", Psychology Research, 7(5), 264-273.

\section{AUTHORS' SHORT BIOGRAPHY}

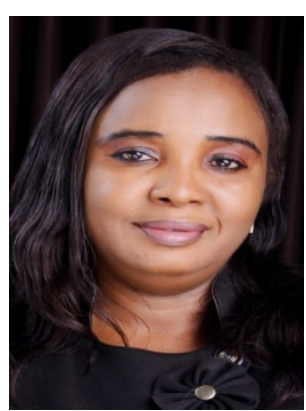

Dr. Chinazor Lady-France OBUNIKE is a Lecturer at the Faculty of Management and Social Science, Department of Business Administration, Alex-Ekwueme Federal University Ndufu-Alike Ikwo Ebonyi State, Nigeria. She studied at UNILAG where she obtained her B.Sc. and M.Sc. in Management and her Ph.D. in Entrepreneurship from Ebonyi-State University, Nigeria. She has passion for research and teaching. Major Areas: Business Management, and Entrepreneurship Contact Address: Alex-Ekwueme Federal University Ndufu-Alike, Ikwo, Faculty of Management and Social Sciences, Department of Business Administration, P.M.B 1010, Abakaliki, Ebonyi State, Nigeria.

ORCID: 0000-0003-4239-7870 